UDC 614.7

DOI: $10.21668 /$ health.risk/2016.4.09.eng

\title{
SANITARY AND EPIDEMIOLOGIC ASSESSMENT OF THE SOIL QUALITY IN MOSCOW AS POSSIBLE PUBLIC HEALTH RISK FACTOR
}

\section{E.E. Andreeva}

Administration of the Federal Service for Supervision of Consumer Rights Protection and Human Welfare in Moscow, 4/9 Grafskiy Pereulok, Moscow, 129626, Russian Federation

The article describes the results of the sanitary-epidemiological evaluation of Moscow soil quality as a possible risk factor for injury to citizens' life and health. It presents a comparative analysis of the dynamic nonstandard soil samples on the sanitary-chemical, parasitological and microbiological indicators in the Russian Federation and in Moscow. The data for the soil quality analysis in the administrative districts of Moscow are summarized. It has been demonstrated, that in the metropolis territory there is a tendency of soil quality improvement in comparison with the year 2012 (according to the sanitary-chemical parameters - by $5.64 \%$, microbiological - by $4.52 \%$ and parasitological - by $0.4 \%$ ). Levels of soil chemical and microbiological contamination in Moscow for the years 2012-2014 were higher than levels in the Russian Federation by 2.43-2.71 and 1.49-2.23 times respectively. The highest proportion of soil samples, that do not meet hygienic standards for chemical indicators in 2014, both in the Russian Federation and in Moscow, was recorded in the zones of influence of the industrial enterprises, highways ( $R F-10.64 \%$ Moscow $-17.65 \%)$ and in the residential areas $(R F-6.53 \%$, Moscow - $17.63 \%)$. More than $50 \%$ of soil samples which do not meet hygienic standards for chemical indicators in 2014, was observed in 4 of the 10 administrative districts of Moscow Central Administrative District $(C A D)-83.3 \pm 36.5 \%$, West $A D-94.4 \pm 31.7 \%$, North $A D-50.0 \pm 25.3 \%$, South AD - 88.9 \pm $30.8 \%$. By the year 2014 the priority pollutants of urban soils in Moscow were lead, zinc, chromium, cadmium, cobalt. In two districts of Moscow the proportion of poor soil samples for bacteriological parameters exceeded $50 \%$ in 2014: South-Eastern Administrative District (54.2 $\pm 29.4 \%)$ and Eastern Administrative District (75.0 \pm $30.0 \%)$. Due to the microbiological parameters the unsatisfactory samples of soil in Moscow demonstrated the excessive indicators of coliforms and enterococci indices. The proportion of soil samples exceeding hygienic standards for parasitological indices ranged from $3.3 \pm 6.5 \%$ to $5.6 \pm 7.7 \%$ in the North AD, South AD and Central AD (non-viable helminthic eggs identified).

Key words: soil quality, soil contamination indicators (sanitary-chemical, parasitological, microbiological), space-dynamic analysis, priority pollutants.

According to Great Medical Encyclopedia, soil is a complex of organic and mineral compounds which emerged on the Earth's crust as a result of physical, chemical, and biological processes [2]. Soil studies are of great interest for hygienists and epidemiologists as soil matters a lot when we speak about sanitary issues of our everyday life. Soil contamination and consequent soil waters contamination lead to epidemics evolvement $[15,23]$. Knowledge on soil characteristics is very important for construction, camping, laying water-supply and sewer networks, projecting cemeteries and sprinkling beds etc. Besides, close relations between soils and climate in this or that area as well as between soils and vegetation make soils studies even more important for tackling settlements hygiene issues, in particular, projecting and constructing cities and villages etc. $[3,6,7,16,17,18]$. Soils are considered to be a special natural membrane (biogeomembrane) which regulates interaction between the Earth's biosphere, hydrosphere and atmosphere. Systemic analysis tells that soils is a multifunctional, heterogeneous, open, and fourphase system (solid phase, liquid phase, gaseous phase, and life forms). Taken form sanitary point of view, soils can cause population

(C) Andreeva E.E., 2016

Elena E. Andreeva - Candidate of Medical Sciences, head, chief state sanitary doctor of the city of Moscow (e-mail: uprav@77.rospotrebnadzor.ru; tel.: +7 (495) 621-70-76). 
endemic diseases; and soil contamination caused by anthropogenic activities leads to additional morbidity cases, both of infectious and non-infectious nature $[1,4,5,9,11-14,19-22]$. As per data provided by the Federal Service for Surveillance over Consumer Rights Protection and Human Well-being [8, 10] soil quality tended to improve in the Russian Federation in 2014 (in comparison with 2012) as per sanitary-chemical, microbiological and parasitological parameters. The same trend also occurred in Moscow (table 1).

The share of examined soil samples not conforming to hygienic standards as per sanitary-chemical parameters decreased by $1.47 \%$ in the RF (in comparison with 2012), and by $5.64 \%$ in Moscow (table 2). However, level of soil chemical contamination in Moscow in 2012-2014 was 2.43-2.71 times higher than in the RF. The level of soil microbiological contamination was also 1.49-2.23 times higher in Moscow than in the RF over the last 3 years. We should note that the share of examined soils samples not conforming to hygienic standards as per parasitological parameters was 1.41-1.94 times lower in Moscow than in the RF on average (table 1).

Microbiological contamination is a parameter which defines soil quality on the territories of children facilities and children playgrounds. In Moscow in 2012-2014 the level of soil microbiological contamination on the territories of children facilities and children playgrounds was 2.16-3.67 times higher than in the RF on average. And its value remained high in spite of the fact that the share of soil samples not conforming to hygienic standards as per microbiological parameters decreased by 1.24 times in the RF and by 1.84 times in Moscow (table 2).

The specific weight of soil samples taken on the territories of children facilities and children playgrounds not conforming to hygienic standards as per sanitary-chemical parameters decreased by 1.07 times in the RF on the whole and by 1.3 times in Moscow (table 2).

The greatest specific weight of soil samples not conforming to hygienic standards as per sanitary-chemical parameters in 2014, both in the RF on the whole and in Moscow, was detected in zones influenced by industrial enterprises, roads and motorways $(10.64 \%$ in the RF, $17.65 \%$ in Moscow), and on areas fir for development $(6.53 \%$ in the RF, $17.63 \%$ in Moscow). At the same time the share of soil samples not conforming to hygienic standards as per sanitary-chemical parameters decreased in 2014 (in comparison with 2012) by 1.05 times in the RF and by 2.88 in Moscow (figure $1)$.

Table 1

Share of examined soil samples not conforming to hygienic standards, $\%$

\begin{tabular}{|l|c|c|c|c|c|c|}
\hline \multirow{2}{*}{ Parameters } & \multicolumn{2}{c|}{2012} & \multicolumn{2}{c|}{2013} & \multicolumn{2}{c|}{2014} \\
\cline { 2 - 7 } & The RF & Moscow & The RF & Moscow & The RF & Moscow \\
\hline Sanitary-chemical & $8,75 \pm 0,20$ & $23,71 \pm 3,66$ & $8,60 \pm 0,20$ & $20,87 \pm 3,06$ & $7,28 \pm 0,19$ & $18,07 \pm 2,77$ \\
\hline Microbiological & $9,33 \pm 0,19$ & $16,35 \pm 1,55$ & $9,04 \pm 0,18$ & $20,23 \pm 1,44$ & $7,9 \pm 0,17$ & $11,83 \pm 1,33$ \\
\hline Parasitological & $1,68 \pm 0,07$ & $1,19 \pm 0,32$ & $1,61 \pm 0,07$ & $0,83 \pm 0,23$ & $1,48 \pm 0,06$ & $0,79 \pm 0,26$ \\
\hline
\end{tabular}

Table 2

Share of examined soil samples taken on the territories of children facilities and children playgrounds and not conforming to hygienic standards, \%

\begin{tabular}{|l|c|c|c|c|c|c|}
\hline \multirow{2}{*}{ Parameters } & \multicolumn{2}{|c|}{2012} & \multicolumn{2}{c|}{2013} & \multicolumn{2}{c|}{2014} \\
\cline { 2 - 7 } & The RF & Moscow & The RF & Moscow & The RF & Moscow \\
\hline Sanitary-chemical & $4,32 \pm 0,26$ & $14,38 \pm 4,15$ & $3,72 \pm 0,24$ & $16,67 \pm 3,96$ & $4,02 \pm 0,25$ & $11,04 \pm 2,94$ \\
\hline Microbiological & $7,53 \pm 0,28$ & $27,61 \pm 4,80$ & $7,24 \pm 0,27$ & $15,54 \pm 3,03$ & $6,03 \pm 0,25$ & $15,01 \pm 3,17$ \\
\hline Parasitological & $0,92 \pm 0,07$ & $0,43 \pm 0,28$ & $0,87 \pm 0,07$ & $0,43 \pm 0,27$ & $0,88 \pm 0,07$ & $0,45 \pm 0,08$ \\
\hline
\end{tabular}




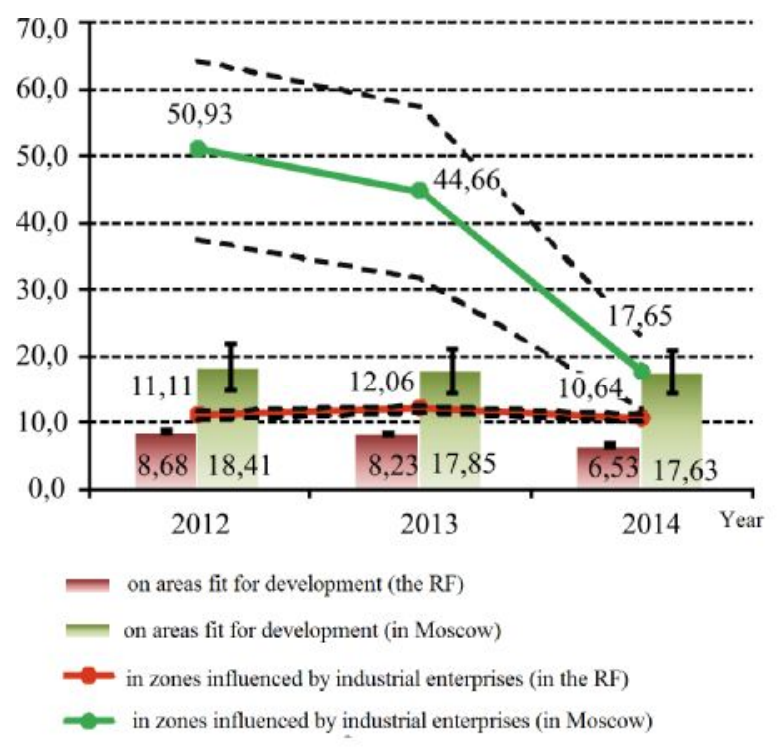

Figure 1. Share of examined soil samples not conforming to hygienic standards as per sanitary-chemical parameters, in the RF and in Moscow, \%

Mercury, lead and cadmium were the main metals causing chemical contamination of soils in the RF. In 2012-2014 share of soils samples not conforming to hygienic standards as per heavy metals content (including lead and cadmium) tended to decrease both in the RF on the whole and in Moscow (table 3).

In 2014 specific weight of samples not conforming to hygienic standards as per heavy metals content decreased (in comparison with 2012) by 1.18 times in the RF (by 1.06 times in Moscow), including lead, by 1.4 times (by 1.61 times in Moscow), cadmium, by 1.6 times (by 1.65 times in Moscow). There were no soils samples not conforming to hygienic standards as per mercury content detected in Moscow either in 2012 or in $2014.0 .33 \%$ of soil samples in the RF contained mercury in concentrations exceeding maximum permissible one.

In 2014 specific weight of samples not conforming to hygienic standards as per heavy metals content decreased (in comparison with 2012) by 1.18 times in the RF (by 1.06 times in Moscow), including lead, by 1.4 times (by 1.61 times in Moscow), cadmium, by 1.6 times (by 1.65 times in Moscow). There were no soils samples not conforming to hygienic standards as per mercury content detected in Moscow either in 2012 or in 2014. $0.33 \%$ of soil samples in the RF contained mercury in concentrations exceeding maximum permissible one.

We should note that, in spite of all the detected positive trends in soils quality as per sanitary-chemical parameters, soils contamination with heavy metals is higher in Moscow than in the RF on average. Thus, in 2014, a share of soil samples not conforming to hygienic standards as per heavy metals content was 3.64 times higher in Moscow than in the RF (table 3).

311 soils samples were examined in 2014 as per sanitary-chemical parameters (331 samples in 2013); 313 soils samples, as per microbiological parameters (341 samples in 2013); 334 soil samples, as per parasitological parameters (576 samples in 2013). On the whole, 958 soils samples were taken for examination in 2014; 198 samples out of the total number didn't conform to hygienic standards (table 4).

In 2014 in Moscow 119 soils samples didn't conform to hygienic standards as per sanitary-chemical parameters $(38.3 \pm 6.9 \%) ; 75$ soils samples, as per microbiological parameters $(24.0 \pm 5.4 \%)$; 4 soil samples, as per parasitological parameters $(1.2 \pm 0.7 \%)$. In 2013 the corresponding figures were 89 samples as per sanitary-chemical parameters $(26.9 \pm 5.6 \%), 85$ samples as per microbiological parameters $(24.9 \pm 5.3 \%), 8$ samples as per parasitological parameters $(1.4 \pm 1.0 \%)$.

In 2014 more than $50 \%$ of soil samples not conforming to hygienic standards as per sanitary-chemical parameters were taken on the territory of 4 out of 10 Moscow administrative districts: $83.3 \pm 36.5 \%$ in $\mathrm{TsAD}^{1}$, $94.4 \pm 31.7 \%$ in $\mathrm{ZAD}, 50.0 \pm 25.3 \%$ in $\mathrm{SAD}$,

\footnotetext{
${ }^{1}$ here and further on: TsAD is Tsentralniy AD, ZAD is Zaoadniy AD, SAD is Severniy AD, YuAD is Yuzhniy AD, VAD is Vostochniy AD, ZelAD is Zelenogradskiy AD, YuZAD is Yugo-Zaoadniy AD, YuVAD is Yugo-Vostochniy AD, SVAD is Severo-Vostochniy AD, SZAD is Severo-Zaoadniy AD.
} 
$88.9 \pm 30.8 \%$ in YuAD (table 4). A share of unsatisfactory samples as per bacteriological parameters exceeded $50 \%$ only in two administrative districts in Moscow, namely YuVAD $(54.2 \pm 29.4 \%)$ and VAD $(75.0 \pm 30.0 \%)$. This parameter didn't exceed $46.7 \pm 24.4 \%$ in other administrative districts. In ZelAD, YuAD and SVAD all the examined soil samples conformed to hygienic standards as per microbiological parameters. A share of soil samples not conforming to hygienic standards as per parasitological parameters varied from $3.3 \pm 1.5 \%$ to $5.6 \pm 2.7 \%$ in $\mathrm{SAD}, \mathrm{YuAD}$ and TsAD. There were no unsatisfactory soil samples as per parasitological parameters registered in all other administrative districts in Moscow (table 4).

Analysis of soil contamination dynamics in Moscow revealed that on the whole specific weight of samples not conforming to hygienic standards as per sanitary-chemical, microbio- logical and parasitological parameters decreased over 2012-2014 (table 5).

A share of soil samples not conforming to hygienic standards as per sanitary-chemical parameters decreased in 2014 by $0.4 \%$ in comparison with 2012. Specific weight of unsatisfactory samples as per sanitary-chemical parameters decreased in 5 administrative districts in Moscow, namely VAD, SAD, YuBAD, SVAD, and TsAD. A share of samples not conforming to hygienic standards increased in 3 administrative districts, namely YuAD, YuZAD, and ZAD. And there were no soil samples not conforming to hygienic standards as per sanitary-chemical parameters registered in 2 administrative districts (ZelAD and SZAS). In 2014, just like in previous years, lead, zinc, chrome, cadmium, and cobalt, were priority contaminants of Moscow city soils.

Share of soil samples not conforming to hygienic standards as per content

Table 3 of certain heavy metals, $\%$

\begin{tabular}{|l|c|c|c|c|c|c|}
\hline \multirow{2}{*}{ Chemical substances } & \multicolumn{2}{|c|}{2012} & \multicolumn{2}{c|}{2013} & \multicolumn{2}{c|}{2014} \\
\cline { 2 - 7 } & The RF & Moscow & The RF & Moscow & The RF & Moscow \\
\hline $\begin{array}{l}\text { Heavy metals, } \\
\text { including: }\end{array}$ & $6,52 \pm 0,19$ & $21,80 \pm 3,55$ & $6,26 \pm 0,18$ & $19,55 \pm 3,15$ & $5,50 \pm 0,17$ & $20,05 \pm 3,20$ \\
\hline - mercury & $0,25 \pm 0,05$ & 0,00 & $0,17 \pm 0,04$ & $1,34 \pm 0,88$ & $0,33 \pm 0,05$ & 0,00 \\
\hline - lead & $2,80 \pm 0,13$ & $9,88 \pm 2,40$ & $2,06 \pm 0,11$ & $5,76 \pm 1,72$ & $2,00 \pm 0,11$ & $6,13 \pm 1,77$ \\
\hline - cadmium & $1,09 \pm 0,08$ & $1,98 \pm 1,07$ & $0,90 \pm 0,07$ & $1,48 \pm 0,88$ & $0,68 \pm 0,07$ & $1,20 \pm 0,78$ \\
\hline
\end{tabular}

Table 4

Soil contamination parameters in populated areas of Moscow as per social-hygienic monitoring data in 2014

\begin{tabular}{|c|c|c|c|c|c|c|c|c|c|c|}
\hline \multirow{4}{*}{$\mathrm{AD}$} & \multirow{4}{*}{$\begin{array}{l}\text { Sampling } \\
\text { points num- } \\
\text { ber }\end{array}$} & \multicolumn{9}{|c|}{ Contamination parameters } \\
\hline & & \multicolumn{3}{|c|}{ Sanitary-chemical } & \multicolumn{3}{|c|}{ Microbiological } & \multicolumn{3}{|c|}{ Parasitological } \\
\hline & & \multirow{2}{*}{$\begin{array}{l}\text { Samples } \\
\text { number }\end{array}$} & \multicolumn{2}{|c|}{$\begin{array}{l}\text { Not conforming to } \\
\text { standards }\end{array}$} & \multirow{2}{*}{$\begin{array}{l}\text { Samples } \\
\text { number }\end{array}$} & \multicolumn{2}{|c|}{$\begin{array}{l}\text { Not conforming to } \\
\text { standards }\end{array}$} & \multirow{2}{*}{$\begin{array}{l}\text { Samples } \\
\text { number }\end{array}$} & \multicolumn{2}{|c|}{$\begin{array}{l}\text { Not conforming to } \\
\text { standards }\end{array}$} \\
\hline & & & units & $\%$ & & units & $\%$ & & units & $\%$ \\
\hline VAD & 16 & 16 & 0 & 0 & 32 & 24 & $75.0 \pm 30.0$ & 32 & 0 & 0 \\
\hline SAD & 15 & 30 & 15 & $50.0 \pm 25.3$ & 30 & 14 & $46.7 \pm 24.4$ & 30 & 1 & $3.3 \pm 1.5$ \\
\hline ZelAD & 5 & 10 & 0 & 0 & 10 & 0 & 0 & 10 & 0 & 0 \\
\hline YuAD & 18 & 36 & 32 & $88.9 \pm 30.8$ & 36 & 0 & 0 & 36 & 2 & $5.6 \pm 2.7$ \\
\hline YuZAD & 12 & 77 & 12 & $15.6 \pm 8.8$ & 63 & 9 & $14.3 \pm 9.3$ & 84 & 0 & 0 \\
\hline $\mathrm{ZAD}$ & 18 & 36 & 34 & $94.4 \pm 31.7$ & 36 & 5 & $13.9 \pm 12.2$ & 36 & 0 & 0 \\
\hline YuVAD & 12 & 24 & 4 & $16.7 \pm 16.3$ & 24 & 13 & $54.2 \pm 29.4$ & 24 & 0 & 0 \\
\hline SVAD & 17 & 34 & 2 & $5.9 \pm 8.1$ & 34 & 0 & 0 & 34 & 0 & 0 \\
\hline SZAD & 11 & 24 & 0 & 0 & 24 & 2 & $8.3 \pm 3.5$ & 24 & 0 & 0 \\
\hline TsAD & 12 & 24 & 20 & $83.3 \pm 36.5$ & 24 & 8 & $33.3 \pm 23.1$ & 24 & 1 & $4.2 \pm 2.2$ \\
\hline Total & 136 & 311 & 119 & $38.3 \pm 6.9$ & 313 & 75 & $24.0 \pm 5.4$ & 334 & 4 & $1.2 \pm 0.7$ \\
\hline
\end{tabular}


Table 5

Dynamics of changes in soil contamination parameters

in populated areas of Moscow over 2012-2014

\begin{tabular}{|l|c|c|c|c|c|c|c|c|c|}
\hline \multirow{3}{*}{ AD } & \multicolumn{7}{|c|}{ A share of soils samples not conforming to hygienic standards, \% } \\
\cline { 2 - 11 } & Sanitary-chemical examination & \multicolumn{2}{c|}{ Microbiological examination } & \multicolumn{3}{c|}{ Parasitological examination } \\
\cline { 2 - 11 } & 2012 & 2013 & 2014 & 2012 & 2013 & 2014 & 2012 & 2013 & 2014 \\
\hline VAD & $56.3 \pm 36.7$ & 0 & 0 & $34.4 \pm 20.3$ & $81.3 \pm 31.2$ & $75.0 \pm 30.0$ & $3.1 \pm 6.1$ & $3.1 \pm 6.1$ & 0 \\
\hline SAD & $63.3 \pm 28.4$ & $73.3 \pm 30.6$ & $50.0 \pm 25.3$ & $63.3 \pm 28.4$ & $10 \pm 11.3$ & $46.7 \pm 24.4$ & $3.3 \pm 6.5$ & $6.7 \pm 9.2$ & $3.3 \pm 1.5$ \\
\hline ZelAD & 0 & 0 & 0 & 0 & 0 & 0 & $0 \pm 0$ & 0 & 0 \\
\hline YuAD & $11.1 \pm 10.9$ & $25 \pm 16.3$ & $88.9 \pm 30.8$ & 0 & $13.9 \pm 12.2$ & 0 & $5.6 \pm 7.7$ & $2.8 \pm 5.4$ & $5.6 \pm 2.7$ \\
\hline YuZAD & $12.5 \pm 14.1$ & $20 \pm 9.2$ & $15.6 \pm 8.8$ & $87.5 \pm 37.4$ & $11.9 \pm 7.4$ & $14.3 \pm 9.3$ & $0 \pm 0$ & 0 & 0 \\
\hline ZAD & $63.9 \pm 26.1$ & $47.2 \pm 22.4$ & $94.4 \pm 31.7$ & $47.2 \pm 22.4$ & $58.3 \pm 24.9$ & $13.9 \pm 12.2$ & $0 \pm 0$ & $2.8 \pm 5.4$ & 0 \\
\hline YuVAD & $37.5 \pm 24.5$ & $2.9 \pm 5.8$ & $16.7 \pm 16.3$ & $29.2 \pm 21.6$ & $32.4 \pm 19.1$ & $54.2 \pm 29.4$ & $0 \pm 0$ & 0 & 0 \\
\hline SVAD & $29.4 \pm 18.2$ & $17.6 \pm 14.1$ & $5.9 \pm 8.1$ & $14.7 \pm 12.9$ & $2.9 \pm 5.8$ & 0 & $0 \pm 0$ & 0 & 0 \\
\hline SZAD & 0 & 0 & 0 & 0 & $9.1 \pm 12.6$ & $8.3 \pm 3.5$ & $0 \pm 0$ & 0 & 0 \\
\hline TsAD & $91.7 \pm 38.3$ & $69.6 \pm 34.1$ & $83.3 \pm 36.5$ & $25 \pm 20$ & $26.1 \pm 20.9$ & $33.3 \pm 23.1$ & $4.2 \pm 8.2$ & $13 \pm 14.7$ & $4.2 \pm 2.2$ \\
\hline TOTAL & $38.7 \pm 7.6$ & $26.9 \pm 5.6$ & $38.3 \pm 6.9$ & $31.6 \pm 6.7$ & $24.9 \pm 5.3$ & $24.0 \pm 5.4$ & $1.9 \pm 1.7$ & $1.4 \pm 1$ & $1.2 \pm 0.7$ \\
\hline
\end{tabular}

Specific weight of soil samples not conforming to hygienic standards as per microbiological agents content decreased by $7.6 \%$ in 2014 in comparison with 2012. The share of unsatisfactory soils samples as per microbiological parameters went down in YuZAD, ZAD, and SVAD; their number grew in VAD, $\mathrm{SAD}, \mathrm{YuVAD}, \mathrm{SZAD}$, and TsAD. The share of unsatisfactory samples remained the same in ZelAD and YuAD.

Soil samples unsatisfactory as per microbiological parameters had increased content of colon bacillus group bacteria and high enterococcus index, but no pathogenic germs (including salmonella) were detected.

A share of soil samples not conforming to hygienic standards as per parasitological parameters decreased by $0.72 \%$ in Moscow in 2014 in comparison with 2012. Decrease in soil parasitological contamination was detected in VAD. There were no changes in this parameter detected in any other administrative district.

Soil quality deviating from hygienic standards as per parasitological parameters occurred in single instances when unviable helminth eggs were detected.
So, hygienic characteristics of soil contamination in Moscow revealed that:

$\square$ soil quality tended to improve both in Moscow and in the RF on the whole in 2014 (in comparison with 2012) as per sanitarychemical (by $1.47 \%$ in the RF, by $5.64 \%$ in Moscow), microbiological (by $1.43 \%$ in the RF, by $4.52 \%$ in Moscow), and parasitological parameters (by $0.2 \%$ in the RF, by $0.4 \%$ in Moscow);

$\square$ the level of soil microbiological contamination in Moscow exceeded average country level by 1.49-2.23 times over the last three years:

$\square$ the share of examined soil samples not conforming to hygienic standards as per parasitological parameters was 1.41-1.94 times lower in Moscow than in the RF on average;

$\square$ the level of soil chemical contamination in Moscow was 2.43-2.71 times higher than in the RF in 2012-2014;

$\square$ the biggest specific weight of samples not conforming to hygienic standards as per sanitary-chemical parameters in 2014 both in the RF and in Moscow was registered in zones influenced by industrial enterprises, roads and motorways $(10.64 \%$ in the $\mathrm{RF}, 17.65 \%$ in 
Moscow) and on areas fit for development (6.53\% in the RF, $17.63 \%$ in Moscow);

$\square$ mercury, lead, and cadmium are priority metals influencing soil chemical contamination in the RF. In 2014 specific weight of samples not conforming to hygienic standards as per heavy metal contamination, decreased by 1.18 in the RF in comparison with 2012 (it decreased by 1.06 in Moscow); it decreased by 1.4 times in respect of lead (by 1.61 in Moscow) and by 1.6 times in respect of cadmium (by 1.65 in Moscow);

$\square$ more than $50 \%$ of soil samples not conforming to hygienic standards as per sanitarychemical parameters were detected in 4 out of 10 administrative districts in Moscow; the figures were $83.3 \pm 36.5 \%$ in TsAD, $94.4 \pm 31.7 \%$ in $\mathrm{ZAD}, 50.0 \pm 25.3 \%$ in $\mathrm{SAD}, 88.9 \pm 30.8 \%$ in YuAD;

$\square$ a share of unsatisfactory samples as per bacteriological parameters exceeded $50 \%$ in two administrative districts in Moscow in 2014, namely YuVAD (54.2 $\pm 29.4 \%)$ and VAD (75.0 $\pm 30.0 \%)$

$\square$ a share of samples not conforming to hygienic standards as per parasitological parameters varied from $3.3 \pm 6.5 \%$ to $5.6 \pm 7.7 \%$ in SAD, YuAD and TsAD;

$\square$ lead, zinc. chrome, cadmium, and cobalt were main contaminants of city soils in 2014;

$\square$ soil samples not conforming to hygienic standards as per microbiological parameters in Moscow had increased number of colon bacillus group bacteria and high enterococcus index;

$\square$ soil quality deviating from hygienic standards as per parasitological parameters was a rare case and occurred only when unviable helminth eggs were detected.

\section{References}

1. Bajdaulet I.O., Namazbaeva Je.I., Dosybaeva G.N., Oblezina A.V., Sabirov Zh.B., Husnutdinova Je.M. Gigienicheskaja ocenka opasnosti zagrjaznenija pochvy svincom [Hygienic evaluation of soil pollution lead hazard]. Uspehi sovremennogo estestvoznanija, 2013, no. 4. pp. $96-99$ (in Russian).

2. Bol'shaja Medicinskaja Jenciklopedija: il [Great Medical Encyclopedia: il.]. 1982, vol. 18, 528 p. (in Russian).

3. Grebeneva O.V., Sakiev K.Z., Otarbaeva M.B., Zhanbasinova N.M. Problemy zagrjaznenija pochvy tverdymi othodami promyshlennyh predprijatij v Kazahstane [Problems of soils pollution with solid industrial waste in Kazakhstan]. Medicina truda i promyshlennaja jekologija, 2014, no. 8, pp. 9-13 (in Russian).

4. Doklad o sostojanii okruzhajushhej sredy v gorode Moskve v 2013 godu [Report on the state of environment in Moscow in 2013]. In: A.O. Kul'bachevskogo ed. Moscow, LARK LTD Publ., 2014, 222 p. (in Russian).

5. Plaksin S.M., Zuev A.G., Knutov A.V., Maksimova S.I. [et al]. Kontrol'no-nadzornaja dejatel'nost' v Rossijskoj Federacii: analiticheskij doklad - 2015 [Control and supervisory activities in the Russian Federation: analytical report - 2015]. Moscow, Nacional'nyj issledovatel'skij universitet «Vysshaja shkola jekonomiki» Publ., 2016, 126 p. (in Russian).

6. Lim T.E., Bek A.V., Alikbaeva L.A. Ocenka vozdejstvija na naselenie Sankt-Peterburga zagrjaznenij pochvy kancerogennymi veshhestvami [Assessment of influence of contamination soil by carcinogenic substances on population of Saint-Petersburg]. Profilakticheskaja i klinicheskaja medicina, 2013, vol. 47, no. 2, pp. 11-15 (in Russian).

7. Makarov O.A., Makarov A.A. Ocenka jekologicheskogo riska zagrjaznenija pochv pridorozhnyh territorij goroda Moskvy [Environmental risk assessment of soil contamination in Moscow roadside areas]. Problemy regional'noj jekologii, 2014, no. 2, pp. 133-139 (in Russian).

8. O sanitarno-jepidemiologicheskoj obstanovke v Rossijskoj Federacii v 2012 godu: Gosudarstvennyj doklad [About a sanitary and epidemiologic situation in the Russian Federation in 2012: State report]. Moscow, Federal'nyj centr gigieny i jepidemiologii Rospotrebnadzora, 2013, 167 p. (in Russian). 
9. O sostojanii okruzhajushhej sredy v gorode Moskve v 2014 godu: Doklad [On the state of environment in Moscow in 2014: report]. In: A.O. Kul'bachevskogo ed. Moscow, DPiOOS Publ.; NIAPriroda Publ., 2015, 384 p. (in Russian).

10. O sostojanii sanitarno-jepidemiologicheskogo blagopoluchija naselenija v Rossijskoj Federacii v 2014 godu: Gosudarstvennyj doklad [On the state of the sanitary and epidemiological welfare of the Russian Federation population in 2014: State Report]. Moscow, Federal'naja sluzhba po nadzoru v sfere zashhity prav potrebitelej i blagopoluchija cheloveka, 2015, 219 p. (in Russian).

11. O sostojanii sanitarno-jepidemiologicheskogo blagopoluchija naselenija $\mathrm{v}$ gorode Moskve $\mathrm{v}$ 2014 godu: Gosudarstvennyj doklad [On the state of the sanitary and epidemiological welfare of the Russian Federation population in 2014: State Report]. Moscow, Upravlenie Rospotrebnadzora po g. Moskva, 2015, 233 p. (in Russian).

12. Osipova N.A., Jazikov E.G., Jankovich E.P. Tjazhelye metally v pochve i ovoshhah kak faktor riska dlja zdorov'ja cheloveka [Heavy metals in soil and vegetables as a risk factor for health of consumers]. Fundamental'nye issledovanija, 2013, no. 8-3, pp. 681-686 (n Russian).

13. Sazonova O.V., Isakova O.N., Gorbachjov D.O., Suhachjova I.F., Komarova M.V., Drozdova N.I. Sreda obitanija i zabolevaemost' naselenija goroda Samary zlokachestvennymi novoobrazovanijami [Environment and malignant neoplasms morbidity of the samara population]. Fundamental'nye issledovanija, 2014, no. 7-2, pp. 357-363 (in Russian).

14. Sazonova O.V., Suhacheva I.F., Berezin I.I., Orlova L.E., Drozdova N.I. Reprezentativnost' rezul'tatov jekologo-gigienicheskoj ocenki pochvy i riski zdorov'ju naselenija Samarskoj oblasti [Representation the results of ecologic and hygienic estimation of soil and risk on health of the population in Samara oblast]. Izvestija Samarskogo nauchnogo centra Rossijskoj akademii nauk, 2012, vol. 14, no. 5-3, pp. 635-640 (in Russian).

15. Sazonova O.V., Suhacheva I.F., Isakova O.N., Molodkina D.A. Dostovernost' sanitarnobakteriologicheskoj ocenki pochvy naselennyh mest $\mathrm{v}$ uslovijah antropogennoj nagruzki na okruzhajushhuju sredu [Reliability of sanitary and bacteriological assessment of the occupied places soil in the conditions of anthropogenous loading on environment]. Izvestija Samarskogo nauchnogo centra Rossijskoj akademii nauk, 2012, vol. 14, no 5-3, pp. 632-634 (in Russian).

16. Sostojanie zagrjaznenija okruzhajushhej sredy Moskovskogo regiona. 2014 god: Ezhegodnyj sbornik informacionno-spravochnyh materialov [State of environmental pollution in the Moscow region. 2014: annual collection of information and reference materials]. Moscow, FGBU «Central'noe UGMS» Rubl., 2015, 47 p. (in Russian).

17. Unguryanu T.N., Gudkov A.B., Nikanov A.N. Ocenka riska dlja zdorov'ja gorodskogo naselenija pri vozdejstvii kontaminantov pochvy [Health risk assessment of soil contaminants for health of urban population]. Profilakticheskaja i klinicheskaja medicina, 2012, no. 1, pp. 101-105 (in Russian).

18. Alexander van Geen, Carolina Bravo, Vladimir Gil, Shaky Sherpa, Darby Jack. Lead exposure from soil in Peruvian mining towns: a national assessment supported by two contrasting examples. Bulletin of the World Health Organization, 2012, vol. 90, no. 12, pp. 869-944.

19. CalEPA. Supplemental Guidance for Human Health Multimedia Risk Assessments of Hazardous Waste Sites and Permitted Facilities. Chapter 7. Assessment of Health Risks from Inorganic Lead in Soil, 1996, 6 p. Available at: https: //www.dtsc.ca.gov/AssessingRisk/upload/forward.pdf (23.10.2016)

20. Haiyang Chena, Yanguo Tenga, Sijin Luc, Yeyao Wangc, Jinsheng Wanga. Contamination features and health risk of soil heavy metals in China. Science of The Total Environment, 2015, vol. 512513, pp. 143-153.

21. MfE 2011. Toxicological Intake Values for Priority Contaminants in Soil. Ministry for the Environment, Wellington, 2011, 155 p. Available at: http: //www.mfe.govt.nz/sites/default/files/toxicological-intake-values-for-priority-contaminants-in-soil.pdf (23.10.2016).

22. Ministry for the Environment. 2011. Methodology for Deriving Standards for Contaminants in Soil to Protect Human Health. Wellington: Ministry for the Environment, 2011, 219 p. Publication number: ME 1055. Available at: http: //www.tcdc.govt.nz/PageFiles/12346/MfE.methodology-for-derivingstandards-for-contaminants-in-soil.June11.pdf (23.10.2016) 
23. Singh Jiwan and Kalamdhad Ajay S. Effects of Heavy Metals on Soil, Plants, Human Health and Aquatic Lif. International Journal of Research in Chemistry and Environment, 2011, vol. 1, no. 2, pp. 1521.

Andreeva E.E. Sanitary and epidemiologic assessment of the soil quality in Moscow as possible public health risk factor. Health Risk Analysis, 2016, no. 4, pp. 66-73. DOI: 10.21668/health.risk/2016.4.09.eng

Received: 23.08.2016

Accepted: 05.12.2016

Published: 30.12 .2016 